\title{
SUSTAINABLE DEVELOPMENT APPROACH TO RESIDENTIAL PLANNING IN THE RAPID GROWTH URBAN AREA: A CASE STUDY IN SINGOSARI DISTRICT, MALANG REGION, EAST JAVA PROVINCE
}

\author{
Arief RACHMANSYAH ${ }^{1}$, Luciana F. HALIM ${ }^{2}$, SOEMARNO
}

DOI: 10.21163/GT_2019. 141.13

\begin{abstract}
:
Urbanization has impact on increasing demand of housing in urban area and drifting of the residence to suburban, therefore on degradation of environmental quality. The development of flats can be a strategy to meet the needs of houses especially for low-income society (LIS). This paper will compare the sustainability between development of landed housing and flats in the same area. The social aspect are limited to the number of houses for LIS that can be serve, the ecological aspect are limited to the oxygen equilibrium, however the economic aspect is limited by the affordability of LIS to purchase the house. The case study was conducted at Bumi Mondoroko Raya Resident, on Singosari District, Malang Region that is directly adjacent to the Malang City. The area of resident is 37.6 ha, it has been built 2985 units of landed houses, however it can accommodate 20976 units of flats. The green open space of landed housing development can produce $16871 \mathrm{~kg} \mathrm{~d}^{-1}$ of oxygen, however the development of flats can produce $107994 \mathrm{~kg} \mathrm{~d}^{-1}$. The calculated price of flats is IDR $190,000,000$ per unit. This price is lower than IDR $284,400,000$ as the standard price of flats in East Java Province.
\end{abstract}

Key-words: Flats, Landed House, Low Income Society.

\section{INTRODUCTION}

Population growth in urban area, as consequence of marital and urbanization, are often not accompanied by the provision of adequate housing, so the backlog is happened especially for low-income-society (LIS). Therefore, the provision of housing for lowincome-society is generally developed on the suburban area due to low prices of land acquisition. Nevertheless, the construction of landed houses models on the suburban needs a conversion of agricultural land. This activity will impact on the decline of food crops production, the increase of runoff coefficient that as trigger of local floods, and environmental degradation such as decreasing air quality, and some social problems.

The peripheral area of city provides the greatest opportunity for productive activity and most favorable areas of residence compared to urban and rural areas. That area has strong city influence, characterized by physical characteristics, land use, aesthetics, population and labor composition changes, and also changes in patterns of orientation and population activity. Munasinghe (1993) states that sustainable development in the aspect of housing is the provision for low-income-society that can balance between the ecological, economic and social dimensions. One of the easy-to-realize policies is to transform horizontal housing into vertical development (flats).

\footnotetext{
${ }^{1}$ Brawijaya University, Faculty of Engineering, Civil Engineering Department, ariefftub@yahoo.com

${ }^{2}$ Public Work Department, Government of Malang Regency, chelsieve@gmail.com

${ }^{3}$ Soil Science Department, Faculty of Agriculture, Brawijaya University.soemarno@ub.ac.id
} 
To distinguish the sustainability status of the landed houses and flats construction, a comparative study of social, ecological and economic aspects has been conducted on the two models of housing development. The selected housing model has land area of $36 \mathrm{~m}^{2}$ and $45 \mathrm{~m}^{2}$. A flat with the same area of $36 \mathrm{~m}^{2}$ is as a comparison. Based on the preliminary research of the flats model for low-income society and the consideration of the social aspect, the model of the apartment building is five floors. There are two flats model for efficiency of land, which one is a building block with corridor and twin block flats (using voids). The using of first floor building is for small business store (kiosk), management room, small mosque, and small parking area. Each floor consists of 20 housing units, a multipurpose room, and a shared laundry room to prevent the slum. The facade of a unit of the flat device an outward-facing terrace is shown as in Fig. 1.

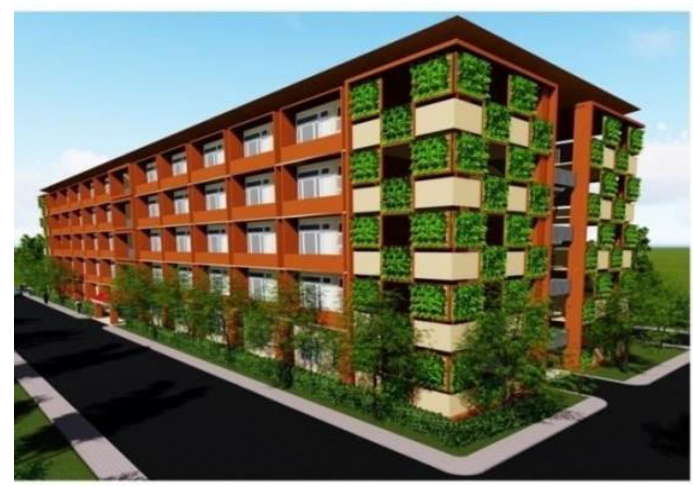

Fig. 1. Design of flats as model.

The results of this study are expected to be a model of sustainable resident development, as a consideration for local and city governments in formulating residential development policies, and as information for low-income-society in choosing the living place.

\section{LOCATION OF CASE STUDY}

Malang City (Kota Malang) is the second largest city in East Java Province, the area of city is $110.1 \mathrm{~km}^{2}$, Malang City is also known as education and tourism city. In 2015 , the population reached 850 thousand inhabitants with density of approximately 7,750 people per $\mathrm{km}^{2}$. The population growth is predicted to reach $0.85 \% \mathrm{yr}^{-1}$. According to data of population growth in each district in Malang City, there was population movement from downtown to borderline area. Malang City is located in the center of Great Malang Area (Fig. 2).

Total area of Malang Region (Kabupaten Malang) is $534.9 \mathrm{~km}^{2}$ with population of 260,000 in 2015 . The average population density is 720 inhabitants per $\mathrm{km}^{2}$ with population growth reach $0.7 \% \mathrm{yr}^{-1}$. In contrary, the population density in the borderline area reaches 3 000 inhabitants per $\mathrm{km}^{2}$, while the population growth is less than $1.2 \% \mathrm{yr}^{-1}$. During the last $5 \mathrm{yr}$, the differences between the necessity and the provision of houses (backlog) for lowincome-society are 11293 unit houses $\mathrm{yr}^{-1}$.

Singosari is one of districts in Malang Region that directly adjacent to Malang City that is rapid growth suburban area. Compared with other districts the residential areas in Singosari are known to be most developed district due to the presence of Surabaya- 
Pandaan - Malang highway. In this district several types of manufacture industries have been developed since $20 \mathrm{yr}$.

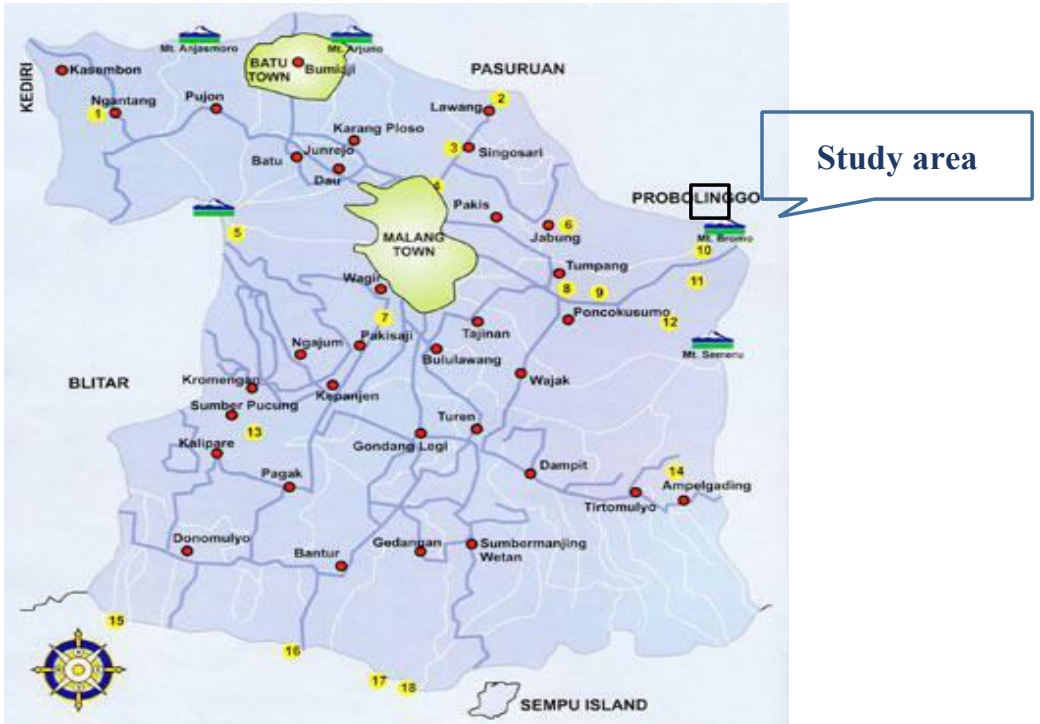

Fig. 2. The administrative Area of Great Malang (Malang Region, Malang City, and Batu City) and the Position of Study Area.

Bumi Mondoroko Raya Resident which is used as research object is located in Singosari district. The total area of this resident area reaches 37.62 ha and has been built as many as 2,985 unit houses that were addressed for low-income society. The green open space and access road is covering 7.64 ha or $21 \%$ of total areas. This study focused on the concept of housing development using flats model in that available land.

\section{METHODS}

The research was held by qualitative and quantitative approach. A qualitative approach was undertaken during preliminary survey to find out the flats model that is interest to the low-income-society. The research was conducted by interview and explained the picture of flats model that have been designed in accordance with regulations. Survey with questionnaire has been conducted to know the socio-economic characteristics of people in study area, and the ability of low-income-society to buy a unit flat.

The concept composing of flats development is based on the results of field surveys and information from developers. The developer information includes the area of resident, number of landed houses, the area of green open space, and selling price of landed house. The modeling was performed to determine the land requirement if the resident was developed using flats model by several scenarios. If the land requirement has been obtained, it can be calculated the availability of green space and oxygen production capability.

The sustainability analysis of social aspect is performed by comparing the number of landed houses or unit of flats for LIS that can be constructed in the same residential area. The ecology dimension is limited by oxygen equilibrium. The equilibrium is calculated on 
an area with the approximate oxygen required for all human activities (Table 1) with the production of oxygen by plants in green open space.

Table 1. Oxygen Requirement for Activities (Wisesa,1998, in Lestari and Jaya, 2005)

\begin{tabular}{|l|l|c|l|}
\hline \multicolumn{1}{|c|}{ Consumer } & \multicolumn{1}{|c|}{ Category } & $\begin{array}{c}\text { The } \mathrm{O}^{2} \text { requirement } \\
\left.\cdot \mathrm{d}^{-1}\right)^{1)}\end{array}$ & Operational time ${ }^{2)}$ \\
\hline Residence & Individual & 0.864 & \\
\hline \multirow{5}{*}{ Motor Vehicle } & Car & 11.63 & $3 \mathrm{~h} \cdot \mathrm{d}^{-1}$ \\
\cline { 2 - 4 } & Loads car & 22.88 & $2 \mathrm{~h} \cdot \mathrm{d}^{-1}$ \\
\cline { 2 - 4 } & Bus & 45.76 & $2 \mathrm{~h} \cdot \mathrm{d}^{-1}$ \\
\cline { 2 - 4 } & Motorcycle & 0.58 & $1 \mathrm{~h} \cdot \mathrm{d}^{-1}$ \\
\hline \multirow{5}{*}{ Cattle } & Buffalo and Cow & 1.702 & \\
\cline { 2 - 4 } & Horse & 1.854 & \\
\cline { 2 - 4 } & Goat and Lamb & 0.314 & \\
\cline { 2 - 4 } & Chicken & 0.167 & \\
\hline Industries & $\begin{array}{l}\text { Boiler machine } \\
\text { and generator }\end{array}$ & 529.41 & \\
& & & \\
\hline
\end{tabular}

Information : ${ }^{1)} 1 \mathrm{~kg} \mathrm{O}_{2}$ equivalent 0,00144 liter $\mathrm{O}_{2}$

The plants in 1 ha of green space require $900 \mathrm{~kg}$ of $\mathrm{CO}_{2}$ to conduct photosynthesis for $12 \mathrm{~h}$, and at the same time, they will produce $600 \mathrm{~kg} \mathrm{O}_{2}$. That data is then used to estimate the availability of oxygen produced by vegetation. To calculate the oxygen requirement can be calculated using the formula as described by Wisesa (1998, in Lestari and Jaya, 2005), that humans oxidize $12552 \mathrm{~J} \mathrm{~d}^{-1}$ of food by utilizing $600 \mathrm{~L}$ of oxygen or $864 \mathrm{~g} \mathrm{of} \mathrm{O}_{2} \mathrm{~d}^{-1}$ and producing $480 \mathrm{~g}$ of $\mathrm{CO}_{2}$, so that the oxygen demand for humans and vehicles can calculated by the formula (1) and formula (2):

$\mathrm{O}_{2}$ requirement of human $=$ population $\times 0.864 \mathrm{~kg} \mathrm{O}_{2}$

$\mathrm{O}_{2}$ requirement of vehicle $=$ type of vehicle $x$ requirement per vehicle

Human life activities always produce carbon dioxide $\left(\mathrm{CO}_{2}\right)$ gas, so it needs plants and Green Space (GOS) that serves to absorb $\mathrm{CO}_{2}$ gas. Plants, other than its function as $\mathrm{CO}_{2}$ absorber as well as oxygen-producing, filtering dust, binding carbon compounds, it is reducing evaporation of water and temperature stabilization. The benefits of plants and green open space can be seen in Table 2 .

Table 2. Utilization of green open space (GOS) and plant for improvement of environment quality (Frick and Setiawan, 2002, in Murbiantoro, 2009)

\begin{tabular}{|l|c|c|}
\hline \multicolumn{1}{|c|}{ Information } & Tree & GOS $1 \mathrm{ha}$ \\
\hline Oxygen production & $1.7 \mathrm{~kg} \cdot \mathrm{h}^{-1}$ & $600 \mathrm{~kg} \cdot \mathrm{d}^{-1}$ \\
\hline Carbon dioxide recipient & $2.35 \mathrm{~kg} \cdot \mathrm{h}^{-1}$ & $900 \mathrm{~kg} \cdot \mathrm{d}^{-1}$ \\
\hline Carbon coated & $6 \mathrm{t}$ & - \\
\hline Dust filtering & - & until $85 \%$ \\
\hline Evaporation of water & $500 \mathrm{~L} \cdot \mathrm{d}^{-1}$ & - \\
\hline Temperatur decreasing & & $4{ }^{\circ} \mathrm{C}$ \\
\hline
\end{tabular}




\section{RESULT AND DISCUSSION}

\subsection{Requirements Analysis of Land Area and Predicted Number of Houses}

\subsubsection{Landed House Model}

The construction of settlement in the study was started in 2004 in the land area of 0.46 ha, and then developed until it reached 37.62 ha. Type of landed house built at the study site is type 36 addressed to low-income-society. Until 2006, the number of current houses is 2985 unit in a land area of $60 \mathrm{~m}^{2}$ to $90 \mathrm{~m}^{2}$ for each house. According to the field surveys, the construction of 1 unit of house tread requires $126 \mathrm{~m}^{2}$, including roads, drainage channels, and public facility (instead of green open space). If the shortcoming of houses necessity (backlog) in Malang, which currently reaches 11293 units, is replaced with landed house model, then the predicted land area needed is 142.3 ha. To comply the backlog of settlement in Malang regency, there will be a land conversion of 142.3 ha and this will continue to grow in line with the increase of human population. Unfortunately, the development of settlement area is predicted to decrease the agricultural area in Malang Regency. This means that the higher level of development, the higher of loss of agricultural land.

\subsubsection{Flats Model}

The offered flats model contains two types: one full block equipped with corridor (Model A); twin block model using void (Model B). Subsequently, several scenarios were developed from the main two types, including the number of floors and the number of occupancy of each block in a total area 37.62 ha, as presented in Table 3.

Table 3. The number of flats unit can be developed after each model

\begin{tabular}{|c|c|c|c|c|}
\hline Scenarios & \multicolumn{2}{|c|}{ MODEL A } & \multicolumn{2}{c|}{ MODEL B } \\
\cline { 2 - 5 } & $\begin{array}{c}\text { Land area per } \\
\text { block }\left(\mathrm{m}^{2}\right)\end{array}$ & $\begin{array}{c}\text { Number of Flats } \\
\text { Unit }\end{array}$ & $\begin{array}{c}\text { Land area per } \\
\text { block }\left(\mathrm{m}^{2}\right)\end{array}$ & $\begin{array}{c}\text { Number of Flats } \\
\text { Unit }\end{array}$ \\
\hline Scenario 1 & 1,115 & 20,976 & 1,309 & 18,492 \\
\hline Scenario 2 & 1,55 & 16,416 & 1,309 & 14,472 \\
\hline Scenario 3 & 1,155 & 11,56 & 1,309 & 10,452 \\
\hline Scenario 4 & 975 & 19,987 & 1,105 & 17,612 \\
\hline Scenario 5 & 975 & 15,666 & 1,105 & 13,804 \\
\hline
\end{tabular}

The analysis results in each model demonstrated that scenario 1 is the most efficient scenario with the requirement of land per unit is $18 \mathrm{~m}^{2}$ to $20 \mathrm{~m}^{2}$ for house type 36 . The result shows that scenario 1 only needs $14 \%$ of the total land area needed to build the landed house. According to the analysis, it could be said that developing flats requires less land. Applying this scenario could give an opportunity to provide more houses, so as to accelerate the decline of the number of backlog.

\subsubsection{Simulation to Overcome Backlog}

Malang residents began to recognize vertical housing or flats model since 2005. That new type of resident area is located in the center of city. The apartment model is fascinated by high-income-society, because of the price is high. Meanwhile, vertical housing in the form of flats is a rental built by the government. This type vertical housing of occupancy is only enthused by migrant workers. Simulation of resident development with a combination of landed house and flats. The comparison for the construction is $1: 2$, i.e one unit of landed 
house compare to two unit of flats. This simulation is able to decrease backlog up to 3126 units in year 2028. This simulation model also creates benefit by reducing conversion of agricultural land by $35 \%$ (Table 4 ).

Table 4. Simulation of housing requirement and provision in Malang region

\begin{tabular}{|c|c|c|c|c|c|c|c|c|}
\hline \multirow[t]{2}{*}{ Year } & \multirow{2}{*}{$\begin{array}{l}\text { Number of } \\
\text { Household }\end{array}$} & \multirow[b]{2}{*}{$\begin{array}{l}\text { Require- } \\
\text { ment of } \\
\text { Landed } \\
\text { House } \\
\text { (Unit) }\end{array}$} & \multirow{2}{*}{$\begin{array}{l}\text { Requirement of } \\
\text { Landed House } \\
\text { and Flats (Unit) }\end{array}$} & \multicolumn{2}{|c|}{ Backlog } & \multicolumn{3}{|c|}{ Land Requirement } \\
\hline & & & & $\begin{array}{l}\text { Landed } \\
\text { House }\end{array}$ & Flats & $\begin{array}{l}\text { Lande } \\
\text { d } \\
\text { House } \\
\text { (ha) }\end{array}$ & $\begin{array}{r}\text { Flats } \\
\text { (ha) }\end{array}$ & $\begin{array}{c}\text { Land } \\
\text { Efficency } \\
(\%)\end{array}$ \\
\hline 2013 & 688,467 & 677,174 & 677,174 & 11,293 & $\begin{array}{c}11,29 \\
3\end{array}$ & 21.42 & 21.42 & 0 \\
\hline 2017 & 700,385 & 684,867 & 684,867 & 15,518 & $\begin{array}{c}15,51 \\
8\end{array}$ & 26.03 & 26.03 & 0 \\
\hline 2018 & 703,397 & 687,037 & 688,122 & 16,360 & $\begin{array}{c}15,27 \\
5\end{array}$ & 27.34 & 17.58 & 35.71 \\
\hline 2023 & 718,650 & 699,625 & 707,007 & 19,025 & $\begin{array}{c}11,64 \\
3\end{array}$ & 34.89 & 22.44 & 35.69 \\
\hline 2028 & 734,235 & 715,692 & 731,109 & 18,543 & 3,126 & 44.53 & 28.63 & 35.71 \\
\hline
\end{tabular}

\subsection{Oxygen Equilibrium Analysis $\left(\mathrm{O}_{2}\right)$}

The availability of green open space (GOS) in settlement area has a very important role in the improving environmental, social interaction, and economic activity. Green open space can also serves as a local climate stabilization that to be more comfortable, providing oxygen and absorb carbon dioxide and other air pollutants. As Aesthetically role, GOS reflects a more harmony and beautiful environment. As social role, GOS can be used as interaction place of family and community.

\subsubsection{Landed House Model}

The area of GOS in location is 7.64 ha, with 827 trees. In Table 2, it is mentioned that every 1 ha of GOS will produce oxygen $\left(\mathrm{O}_{2}\right)$ as much as $600 \mathrm{~kg} \cdot \mathrm{d}^{-1}$ and absorb carbon dioxide $\left(\mathrm{CO}_{2}\right)$ as much as $900 \mathrm{~kg} \cdot \mathrm{d}^{-1}$ within $12 \mathrm{~h}$. Every tree can produce oxygen $\left(\mathrm{O}_{2}\right)$ as much as $1.7 \mathrm{~kg} \cdot \mathrm{h}^{-1}$ or equivalent to $20.4 \mathrm{~kg} \cdot \mathrm{d}^{-1}$ and absorb $\mathrm{CO}_{2}$ as much as $2.35 \mathrm{~kg} \cdot \mathrm{h}^{-1}$ or $28.2 \mathrm{~kg} \cdot \mathrm{d}^{-1}$ (Table 5).

Table 5. Oxygen $\left(\mathrm{O}_{2}\right)$ production and carbondioxide $\left(\mathrm{CO}_{2}\right)$ absorption in the study area by landed house development

\begin{tabular}{|c|c|c|c|c|c|c|c|}
\hline \multicolumn{3}{|c|}{ Area of Green Open Space (GOS) } & \multicolumn{3}{|c|}{ Nimber of Trees } & \multirow[b]{2}{*}{$\begin{array}{c}\text { Total of } \\
\text { Oxygen } \\
\text { Production } \\
\left(\mathrm{O}_{2}\right) \\
\mathrm{kg} / \mathrm{d}\end{array}$} & \multirow{2}{*}{$\begin{array}{c}\text { Total of } \\
\text { Adsorption } \\
\left(\mathrm{CO}_{2}\right) \\
\mathrm{kg} / \mathrm{d}\end{array}$} \\
\hline 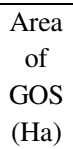 & $\begin{array}{c}\text { Oxygen } \\
\text { Production } \\
\left(\mathrm{O}_{2}\right) \\
\mathrm{kg} / \mathrm{d}\end{array}$ & $\begin{array}{c}\text { Adsorption } \\
\left(\mathrm{CO}_{2}\right) \\
\mathrm{kg} / \mathrm{d}\end{array}$ & $\begin{array}{l}\text { Number } \\
\text { of Trees }\end{array}$ & $\begin{array}{c}\text { Oxygen } \\
\text { Production } \\
\left(\mathrm{O}_{2}\right) \\
\mathrm{kg} / \mathrm{d}\end{array}$ & $\begin{array}{c}\text { Adsorption } \\
\left(\mathrm{CO}_{2}\right) \\
\mathrm{kg} / \mathrm{d}\end{array}$ & & \\
\hline 7.64 & 4,586 & 6,879 & 606 & 12,362 & 17,089 & 16,948 & 23,968 \\
\hline
\end{tabular}

The number of residents in study area is 11320 . Based on questionnaires survey to 147 households, the number of vehicles could be estimated. Then, this result is converted to the number of family, so it is known the number of vehicles owned by citizens. Further, the calculation of the amount of oxygen demand for population activity can be referred to Table 1. The result of calculation of oxygen requirement and production in the study location is $9409 \mathrm{~kg} \cdot \mathrm{d}^{-1}$ (Table 6). After the calculation it is concluded that, the oxygen equilibrium in existing the study area with landed house model is still surplus as much as $7.539 \mathrm{~kg} \cdot \mathrm{d}^{-1}$. 
Table 6. Comparation between production and requirement of $\mathrm{O}_{2}$ in the study area

\begin{tabular}{|c|c|c|c|}
\hline $\begin{array}{c}\text { Area of } \\
\text { GOS (ha) }\end{array}$ & Number of tree & $\begin{array}{c}\mathrm{O}_{2} \text { Production } \\
\left(\mathrm{kg} \cdot \mathrm{d}^{-1}\right)\end{array}$ & $\begin{array}{c}\text { O2 Requirement } \\
\left(\mathrm{kg} \cdot \mathrm{d}^{-1}\right)\end{array}$ \\
\hline 7.64 & 827 & 16.948 & 9.409 \\
\hline
\end{tabular}

\subsubsection{Flats Model}

In the Law of the Republic of Indonesia number 26 year 2007 about Spatial Planning explained that the proportion of green open space in urban is minimum $30 \%$ of the development area. After the simulation results with the flats model and by assuming that one unit of flats can be habited by four people, the number of population in the study area is estimated as 42000 to 84000 (Table 7). It is four times to seven times more than the landed house.

Based on the analysis results of the land requirement for flats, available green open space will be known. The calculation showed that the area of GOS can be obtained 10.7. After the available space is known, then the number of planted trees can be counted. Based on Table 2 it can be calculated the amount of produced oxygen $\left(\mathrm{O}_{2}\right)$ and of aborbed carbon dioxide $\left(\mathrm{CO}_{2}\right)$. The green open space of resident development with the flats model $\mathrm{A}$ and model B can produce oxygen as much as $108000 \mathrm{~kg} \cdot \mathrm{d}^{-1}$, maximum of $80000 \mathrm{~kg} / \mathrm{d}$, and a minimum surplus of $28000 \mathrm{~kg} \cdot \mathrm{d}^{-1}$. More detailed calculations are presented in Table 7.

Table 7. Comparison between $\mathrm{O}_{2}$ production and requirement in study area if flats development

\begin{tabular}{|c|c|c|c|c|c|c|c|c|c|}
\hline \multirow{2}{*}{\multicolumn{2}{|c|}{$\begin{array}{c}\text { Area of } \\
\text { GOS } \\
\text { (ha) }\end{array}$}} & \multirow[t]{2}{*}{$\begin{array}{l}\text { Number of } \\
\text { Flats (unit }\end{array}$} & \multirow{2}{*}{$\begin{array}{c}\text { Number of } \\
\text { nhabitant or } \\
\text { Flats } \\
\text { (one unit fo } \\
\text { four person) }\end{array}$} & \multicolumn{2}{|c|}{$\begin{array}{l}\text { Oxygen Requirement } \\
(\mathrm{kg} / \mathrm{d})\end{array}$} & \multirow{2}{*}{$\begin{array}{l}\text { Number of } \\
\text { Trees } \\
\text { planted per } \\
\text { Ha }\end{array}$} & \multirow{2}{*}{\begin{tabular}{|c|} 
Number of \\
Trees in \\
Green Open \\
Space (GOS)
\end{tabular}} & \multirow{2}{*}{$\begin{array}{c}\text { Oxygen } \\
\text { Production } \\
\left(\mathrm{O}_{2}\right) \\
\left(\mathrm{kg} \cdot \mathrm{d}^{-1}\right)\end{array}$} & \multirow{2}{*}{$\begin{array}{c}\text { Surplus } \\
\text { Oxygen } \\
\left(\mathrm{O}_{2}\right) \\
\left(\mathrm{kg} \cdot \mathrm{d}^{-1}\right)\end{array}$} \\
\hline & & & & (Human) & (Vehicle) & & & & \\
\hline \multicolumn{10}{|c|}{ SCENARIO OF MODEL A } \\
\hline 1 & \multirow[t]{5}{*}{10.72} & 20976 & 83906 & 72494 & 11788 & \multirow[t]{5}{*}{494} & \multirow[t]{5}{*}{5294} & \multirow[t]{5}{*}{107994} & 23712 \\
\hline 2 & & 16416 & 65665 & 56734 & 9225 & & & & 42034 \\
\hline 3 & & 11856 & 47425 & 40975. & 6662 & & & & 60356 \\
\hline 4 & & 19987 & 79949 & 69075 & 11232 & & & & 27686 \\
\hline 5 & & 15666 & 62663 & 54140 & 8803 & & & & 45050 \\
\hline \multicolumn{10}{|c|}{ SCENARIO OF MODEL B } \\
\hline 1 & \multirow[t]{5}{*}{10.72} & 18492 & 73968 & 63908 & 10392 & \multirow[t]{5}{*}{494} & \multirow[t]{5}{*}{5294} & \multirow[t]{5}{*}{107994} & 33694 \\
\hline 2 & & 14472 & 57888 & 50015 & 8133 & & & & 49846 \\
\hline 3 & & 10452 & 41808 & 36122 & 5874 & & & & 65998 \\
\hline 4 & & 17612 & 70448 & 60867 & 9897 & & & & 37230 \\
\hline 5 & & 13804 & 55216 & 47706 & 7757 & & & & 52530 \\
\hline
\end{tabular}

\subsection{Ability and Affordability of Low Income Society}

The ability of low-income-society to buy a home is determined by how much income in the household, so they have the ability to pay the mortgage while still able to meet the basic needs of their life. The calculation of the affordability on landed houses use the concept of income earning (Income Affordability) is:i) if the value of IK-KP does not exceed three, then the settlement can be said to be affordable, ii) if the value of IK-KP more than three, then the settlement is less affordable. The income affordability index (IK-KP) is calculated using the comparison of median price of house or flats $\left(\mathrm{HJ}_{\text {median }}\right)$ to the median income of household $\left(\mathrm{PK}_{\text {median }}\right)$. 


\subsubsection{Landed House}

The selling price of a house for low-income society has been arranged by the government as an effort to control the price escalation. The housing developers in this study area are consistent to that price, which is about IDR 125,000,000. The result of conducted survey show that the average income of LIS in this study area, is IDR 63,700,000 per annual. Thus the price of a landed house offered by the developer is still affordable by lowincome-society.

\subsubsection{Flats Model}

In the existing resident, it can be concluded that landed house price is affordable for the low-income-society. What about the flats built on the principle of sustainability, whether the selling price is still competitive, is the design of a flat with Model A or Model B still within the limits of low-income-society's affordability.

To know the reasonable price of flats development, it is necessary to understanding the principle aspects of the price calculation for a unit flats: the price of land, the number of units and building blocks can be developed, the capability of low-income-society, mortgages and mortgage interest. Before calculating the selling price of flats, it is necessary to know the affordability of low-income-society to have purchased the landed house at the study area. The index of maximum affordability selling price is can calculated using Formula (3):

$$
\boldsymbol{H J}_{\text {median }}=3 \times \text { IDR } 63700000=\text { IDR } 191100000
$$

Therefore the calculation of production price of a flat should be lower than IDR $191,000,000$, so to meet the affordability index of LIS. The calculation results of flats houses development can still be affordable for low-income-society (LIS) and able to provide benefits for developers. The several scenarios that have been made, Model A scenario 1, have the opportunity to give more benefits for the developer (Table 8).

The regulation of the Minister of Public Works and Settlement number 425/KPTS/M/2015 on the limit of selling price of houses that can be obtained through the financing of the ownership, it mentioning the limitation of the flats selling price in East Java is below of IDR $284,400,000$ for type $36 \mathrm{~m}^{2}$, or the most expensive selling price in per $\mathrm{m}^{2}$ is IDR 7,900,000. If the selling price uses the most sales price limits, then the affordability index (IK-KP) purchasing capability can calculated using Formula (4):

$$
\begin{aligned}
(I K-K P) & =\frac{\mathbf{2 8 4 4 0 0 0 0 0}}{\mathbf{6 3 7 0 0 0 0 0}} \\
& =4.46(\text { not affordable })
\end{aligned}
$$

\section{CONCLUSIONS}

\subsection{Ability}

Based on the discussion section it can be concluded that by the sustainable development approach on the provision of housing for low-income-society with flats model is better than the landed house model. The conclusion of this research is as follows:

i) The residential development by landed house model in the urban and suburban areas will trigger an increase in the conversion of agricultural land. In the next stage will affect to declining of the food production, the availability of green open space, and increasing of the runoff water. 
Table 8. Calculation of salling price (Indonesian Rupiahs / IDR) of flats

\begin{tabular}{|c|c|c|c|c|c|c|}
\hline \multirow[b]{2}{*}{$\begin{array}{l}\text { Scenario } \\
\text { of Flats }\end{array}$} & \multirow[b]{2}{*}{$\begin{array}{l}\text { Cost } \\
\text { Production } \\
\text { before profit }\end{array}$} & \multicolumn{3}{|c|}{ Sale Price } & \multirow[b]{2}{*}{$\begin{array}{c}\text { Total Sale } \\
\text { Price (in } \\
\text { million) }\end{array}$} & \multirow[b]{2}{*}{$\begin{array}{l}\text { Profite of } \\
\text { Developer }\end{array}$} \\
\hline & & $\begin{array}{l}2^{\text {nd }} \text { Floor } \\
\text { (in } \\
\text { million) }\end{array}$ & $\begin{array}{l}1^{\text {st }} \text { Floor } \\
\text { (in } \\
\text { million) }\end{array}$ & $\begin{array}{l}\text { Kios (in } \\
\text { million) }\end{array}$ & & \\
\hline \multicolumn{7}{|c|}{ Model A } \\
\hline 1 & $\begin{array}{c}19,150,000,00 \\
0\end{array}$ & 190 & 350 & 360 & 21,920 & $\begin{array}{c}2,770,000,00 \\
0\end{array}$ \\
\hline 2 & $\begin{array}{c}15,685,000,00 \\
0\end{array}$ & 190 & 350 & 360 & 18,120 & $\begin{array}{c}2,435,000,00 \\
0\end{array}$ \\
\hline 3 & $\begin{array}{c}12,220,000,00 \\
0\end{array}$ & 190 & 350 & 360 & 14,320 & $\begin{array}{c}2,100,000,00 \\
0\end{array}$ \\
\hline 4 & $\begin{array}{c}16,321,428,57 \\
1\end{array}$ & 190 & 350 & 360 & 18,180 & $\begin{array}{c}1,858,571,42 \\
9\end{array}$ \\
\hline 5 & $\begin{array}{c}13,396,428,57 \\
1\end{array}$ & 190 & 350 & 360 & 15,140 & $\begin{array}{c}1,743,571,42 \\
9\end{array}$ \\
\hline \multicolumn{7}{|c|}{ Model B } \\
\hline 1 & $\begin{array}{c}19,620,838,30 \\
8\end{array}$ & 190 & 350 & 360 & 21,920 & $\begin{array}{c}2,299,161,69 \\
2\end{array}$ \\
\hline 2 & $\begin{array}{c}16,083,838,30 \\
8\end{array}$ & 190 & 350 & 360 & 18,120 & $\begin{array}{c}2,036,161,69 \\
2\end{array}$ \\
\hline 3 & $\begin{array}{c}12,546,838,30 \\
8\end{array}$ & 190 & 350 & 360 & 14,320 & $\begin{array}{c}1,773,161,69 \\
2\end{array}$ \\
\hline 4 & $\begin{array}{c}16,775,350,84 \\
0\end{array}$ & 190 & 350 & 360 & 18,180 & $\begin{array}{c}1,404,649,16 \\
0\end{array}$ \\
\hline 5 & $\begin{array}{c}13,778,350,84 \\
0\end{array}$ & 190 & 350 & 360 & 15,140 & $\begin{array}{c}1,361,649,16 \\
0\end{array}$ \\
\hline
\end{tabular}

ii) Land requirement for type 36 house for low income society is high, i.e. about $126 \mathrm{~m}^{2}$ per unit. In the case of a residential development by flats model on the same size area it can be built four times to six times more houses. This will be instrumental to closing the imbalance between demand and supply (backlog) of housing for low-income society (LIS) in the urban area.

iii) Despite an increase in the number of housing that can be developed on the same land area, the residential development of flats is able to provide more area of green open space (GOS). The calculation of oxygen equilibrium shows a much larger surplus, although the number of occupants is also four to six times more.

iv) In addition to the socio-cultural aspects of the residential development by flats model for low-income-society in Malang City and its surrounding areas, it also faces problems related to higher selling prices than landed house for the same type, although the selling price is lower than the buying affordability of low-income society.

\subsection{Recommendation}

Some suggestions that can be proposed after the results of this study are as follows:

i) It is imperative to draw up the urban and suburban housing development policies that lead to sustainable flats models.

ii) It is important to consider giving incentives in the form of license procedure and reducing local taxes for investors who provide housing for low-income society (LIS), especially those who want to build with flats model. 
iii) The residential development in Malang City and surrounding areas still require active supporting of central and provincial government synergistically in the funding system so that low-income society (LIS) can have a comfortable and healthy home.

iv) The determination of the selling price of the owned flats by the Central Government should be prepared for every urban area.

\section{R E F E R E N C E S}

Abdulghani, S., (2008) Neighberhood Factors in Private Low-cost Housing in Malaysia. Habitat International, 32(4), 485-493.

Baker, E., Bentley, R., Lester, L., and Beer, A., (2016) Housing Affordability and Residential Mobility as Drivers of Locational Inequility. Applied Geography, 72, 65-75.

Betram, C. \& Rehdanz, K. (2015) The Role of Urban Green Open Space for Human Well- Being, Ecological Economics, 120, 139-152.

Brack, C. L., (2002) Pollution Mitigation and Carbon Sequestration by an Urban Forest, Environmental Pollution, 116 (1), 195-200.

Ding, C. \& Zhao, X., (2014) Land Market, Land Development and Urban Spatial Structure in Beijing. Land Use Policy, 40, 83-90.

Douglas, O., Scott, M. \& Lennon, M., (2017) Green Open Space Benefits for Health and Human Being: A Life-Course Approach for Urban Planning, Design, and Management. Cities, 66, 53-62.

Escobedo, F., Varela, S., Zhao, M., Wagner, J.E. \& Zipperer, W. (2010) Analyzing the Efficacy of Subtropical Urban Forest in Offsetting Carbon Emmisions from Cities. Environmental Science \& Policy, 13(5): 362-372.

Batisani, N. \& Yarnal, B. 2011. Elasticity of capital-land substitution in housing construction, Gaborone, Botswana: Implications for smart growth policy and affordable housing. Landscape and Urban Planning, 99(2): 77-82.

Kusnadi, H. (2002) Study about House Demand in Jakarta, Bogor, Depok, Tangeran, and Bekasi. Thesis, Institut Pertanian Bogor, Bogor, Indonesia.

Minister of Public Works and Settlement, Permen PUPR No 425/KPTS/M/2015, Government Regulation No 425/KPTS/M/2015 about Selling Credit/Prosperous Financing Ownership House Price Restriction], Minister of Public Works and Settlement, Retrieved from https://pembiayaan.pu.go.id/cdn/dl/peraturan/kepmenPUPR_425_2015.pdf, [Accessed March 2019].

Lestari, R. A. E \& Jaya, I. N. S. (2005) Use of Remote Sensing Technologies Satellite And GIS For Determining Urban Forest Area: A Case Study in Bogor City, West Java. Jurnal Manajemen Hutan Tropika, XI(2): 55-69.

Munasinghe, P. C. M. (1993) Environmental Economics and Suitanable Development, Retrieved from World Bank. http://documents.worldbank.org/curated/en/638101468740429035/Environmentaleconomics-and-sustainable-development 21th March 2017 [Accessed March 2019].

Murbiantoro, T. (2009) Vertical housing model development for sustainable housing, Dissertation, Institut Pertanian Bogor, Bogor, Indonesia.

Chabbi-Chemrouk, N. \& Driouèche, N. (2011) Urban Solidarity, A Key Issue to Sustainable Human Settlements. 2011 International Conference on Green Buildings and Sustainable Cities. Procedia Engineering, 21(2011): 707 - 710.

Zhang, C. (2015) Income Inequility and Access to Housing: Evidence from China, China Economic Review, 36, 261-271. 